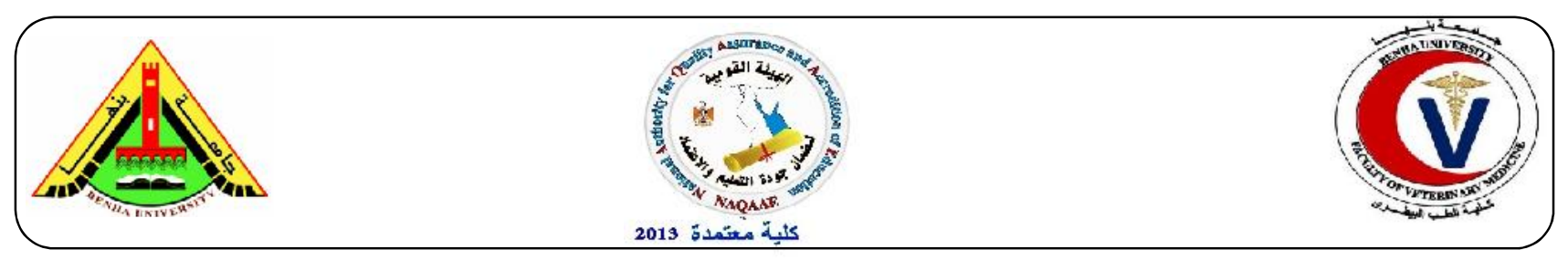

\title{
Optimizing culture conditions for increasing production of vero cell
}

\author{
Gabr. F. El-Bagoury ${ }^{1}$, Ehab. M. EL-Nahas ${ }^{1}$, Lila Abdelazeem², Azza. M. Mohamed ${ }^{2}$ \\ ${ }^{1}$ Department of Virology, Faculty of Veterinary Medicine, Benha University \\ ${ }^{2}$ Veterinary Serum and Vaccine Research Institute, Abbasia, cairo.
}

\section{A B S T R A C T}

The key to achieving maximum yields from microcarrier cultures is by using the optimization factors as replenishment of vero cell culture media during growth, the inoculation density on the proportion of microcarriers bearing cells, stirring speed on the growth of vero cell on cytodex 3 , culture volume and headspace on cell yield from closed microcarrier system, various culture media, various types of the serum, control of $\mathrm{PH}$, microcarrier concentration and modified initial culture procedure. The result reveled that the higher cell yield obtained after replenishment of culture media every three day, the optimum concentration of microcarrier is to be $3 \mathrm{mg}$ cytodex $/ \mathrm{ml}$, the optimum inoculation density $15 \times 10^{6}$ cells/mg cytodex microcarrier is required, the higher cell yield obtained by using (medium 199) containing high amount of amino acid at low density of the cell higher than Dulbecco's modification of Eagles's medium (DME) in higher density of the cell, fetal calf serum gave higher cell yield in the first three days in the culture, $60 \mathrm{rpm}$ was the optimum stirring speed to get higher cell yield, addition of 10-25 m Hepes helped in maintaining the PH around 7.3-7.4 this gave higher cell yield, reduced the head space not more than half full of the culture give a higher result and the modified in initial culture procedure during the growth culture give higher results. The obtained result maximizing the yield of the vero cell production on acytodex-3 microcarrier culture system.

Keywords: cytodex-3 microcarriers, Initial culture, Stirring speed, HEPES solutions, Serum supplements.

(http://www.bvmi.bu.edu.eg) (BVMJ-34(1): 474-482, 2018)

\section{INTRODUCTION}

Vero cells are derived from normal kidney cells; because the cells are not transformed, they have not lost their contact inhibition. When these cells reach confluency, they stop growing and start to die; therefore, it is extremely important to monitor Vero cells and to subculture them as they form confluent monolayers. Actively growing Vero cell cultures double approximately every 24 hours (Nahapetian et al. 1986).
The growth and maintenance of Vero cells using DMEM as the culture medium is a very common culture medium, a variety of other media can also be successfully used with Vero cells) for a description of different culture media that can be used with mammalian cell lines (Sato and Kan, 2001).

So, in our study we using alternative microcarrier technique systems that produce high yield culture of a wide range of animal cell ranging from milliliters to several hundred 
liters has been optimized for efficient attachment and spreading of cells and its size and density are optimized to facilitate even suspension and give good growth and high, yield of cells, so, to maximize Vero cell production by this system must provide several factors and conditions as concentration of the microcarrier, $\mathrm{PH}$ of the culture, serum used, stirring speed, incolum condition of the culture, types of media used.

So, this study was planned to maximize the vero cell production in acytodex-3 micro carrier culture system.

\section{Materials and methods}

\subsection{Vero cell line:}

African green monkey kidney (Vero) cell line was propagated on minimum essential medium (MEM) supplemented with $10 \%$ fetal calf serum at Veterinary Serum and Vaccine Research Institute, Abbassia, Cairo, Egypt.

\subsection{Cytdex-3 Microcarrier culture:}

Cytodex 3 microcarriers (Solo HILL Engineering Inc. USA) Cytodex 3 microcarriers consist a surface of denatured collagen covalently bound to a matrix of crosslinked dextran. The amount of denatured collagen bound to the microcarrier matrix is approx. $60 \mu \mathrm{g} / \mathrm{cm} 2$ and results in maximum cell yields. The denatured collagen (MW 60,000200,000) is derived from pig skin type I collagen which has been extracted and denatured by acid treatment, concentrated and purified by an ion exchange step and steam sterilized before being coupled to the microcarrier matrix these microcarrier combine the advantages of collagen coated culture surfaces with the advantages and possibilities of microcarrier culture cytodex 3 microcarriers can also be used according to the manuiacturers instructions and there are many types of it as Cytodex 1, 2, 3 and collagen but in our study we used Cytodex 3 as it used with vero cell and prepared ad follow:

a. Briefly transfer $250 \mathrm{mg}$ of microcarriers beads into Celstir spinner flask (Wheaton Science Products, USA) consists of a borosilicate glass flask with an integral cap and magnetic impeller assembly. Add $30 \mathrm{ml}$ of deionized water before autoclaving at $121^{\circ} \mathrm{C}$ for at least 30 minutes; decant the autoclaved liquid through pipette aid.

b. Microcarriers cultures were established by inoculating cells ( $2 \times 10^{5}$ cells $/ \mathrm{ml}$ ) into growth medium containing $250 \mathrm{mg}$ microcarriers beads $/ 1000 \mathrm{~mL}$. The cultures were maintained in celstirs in incubator equipped with a stir plate set at $50 \mathrm{rpm}$.

\subsection{Optimization factors:}

1.Optimization of replenishment, vero cell culture media. the depletion of medium components during growth of vero cells in micro carrier culture. Cells were cultured in Dulbecco's modification of Eagles's medium (DME) supplemented with $15 \mathrm{~m} \quad \mathrm{M}$ Hydroxyethylpiperazine ethane sulphonic acid (HEPES). 5\% (v/v) call qerum and 1\% (w/v) tryptose phosphate broth and containing cytodex 3 microcarriers $(5 \mathrm{mg} / \mathrm{ml})$ after 3 days the culture medium was replaced by fresh medium or was removed and supplemented with cysteine $(30 \mathrm{mg} / \mathrm{ml})$, glutamine $(0.3 \mathrm{mg} / \mathrm{ml})$, inositol $(2 \mathrm{mg} / \mathrm{ml})$, glucose $(2 \mathrm{mg} / \mathrm{ml})$, choline HCL $(1 \mathrm{mg} / \mathrm{ml})$ and $1 \%$ $(\mathrm{v} / \mathrm{v})$ calf serum the medium was well mixed and returned to the culture control cultures were not refed

2.Optimization of inoculation density on the proportion of micro carriers bearing cells at the plateau stage of culture. Culture contained 3 mg Cytodex 3/ml final volume were either stirred continuously at $60 \mathrm{rpm}$ or started with a reduced volume and intermittent stirring before the culture was diluted to the final 
volume and stirred at $60 \mathrm{rpm}$ The proportion of micro carriers bearing cells was determined after 7 days.

3.Optimization stirring speed on the growth of vero cells on Cytodex 3 micro carriers (30 rpm, $40 \mathrm{rpm}, 60 \mathrm{rpm}, 90 \mathrm{rpm}, 120 \mathrm{rpm}$ ). all cultures were $250 \mathrm{ml}$ and contained $3 \mathrm{mg}$ cytodex $3 / \mathrm{ml}$. culture vessels were traditional magnetic spinner vessels, and the cultures were stirred from the moment of inoculation in the final culture volume.

4.Optimization of culture volume and headspace volume on cell yields from a closed micro carrier culture system. Cultures were contained in traditional magnetic spinner vessels (Bellco) with a total internal volume $\left(\mathrm{V}_{\mathrm{T}}\right)$ of $500 \mathrm{mls}$. Cultures of various volumes $\left(\mathrm{V}_{\mathrm{M}}\right)$ were inoculated with Vero cells $\left(8 \times 10^{4}\right.$ cells $/ \mathrm{ml}$ ) and stirred at 50-60 rpm and cell yield was determined at the plateau stage of the culture cycle (day 8) $50 \%$ of the culture medium was changed on day 3 and (day 6) .

5.Optimization of various culture media on the growth of (Vero) on Cytodex microcarriers. Dulbecco's modification of Eagles's medium (DME) Medium 199) All media were supplemented with $10 \%(\mathrm{v} / \mathrm{v})$ foteal calf serum. (sigma) Cultures contained $5 \mathrm{mg}$ Cytodex $3 / \mathrm{ml}$ and were stirred at $60 \mathrm{rpm}$ for the culture period. In all experiments $50 \%$ of the medium was changed on day 3 .

6.Optimization of various types of serum supplement on the growth of monkey kidney cells (Vero) in microcarrier cultures. Cells were cultured in modified DME medium containing $3 \mathrm{mg}$ Cytodex $3 / \mathrm{ml}$ and various serum supplements. $10 \%$ foetal calf serum, $5 \%$ foetal calf serum and 5\% newborn calf serum, $5 \%$ foetal calf serum changed to $5 \%$ newborn calf serum on day $3,10 \%$ newborn calf serum, $10 \%$ horse serum.
7.Optimization of control of $\mathrm{pH}$ on the growth of vero cells in micro carrier cultures. Cultures $(400 \mathrm{ml})$ were contained in sealed spinner vessels and stirred continuously at $50 \mathrm{rpm}$. Culture medium (DME, based on Earle's salt solution) was with or without 10m M HEPES. The $\mathrm{pH}$ of the medium without HEPES was initially 7.4 but varied between 7.0 and 8.0 during the culture cycle. The $\mathrm{pH}$ of the medium containing HEPEs was maintained at $7.3-7.4$ The culture medium was changed on day 4 . The difference in cell yields was largely due to higher proportion of empty micro carriers in the culture without $\mathrm{pH}$ control.

8.Optimization of inoculation density and initial culture procedure on the growth of Vero cells on Cytodex 3 micro carrier cultures ware inoculated with cells and stirred immediately in the final volume, $(60 \mathrm{rpm})$ or were cultured in a reduced volume during the attachment stage of culture the modified initial culture procedure involved stirring for $1 \mathrm{~min}(30 \mathrm{rpm})$ every $60 \mathrm{~min}$ in $1 / 3$ of the final culture volume. After $4 \mathrm{~h}$ the culture was diluted to the final volume and stirred $(60 \mathrm{rpm})$. Cultures contained $3 \mathrm{mg}$ Cytodex 3/m final volume.

9. Optimization of initial culture procedure on the attachment efficiency of Vero cells. Cultures containing $5 \mathrm{mg}$ Cytodex $3 / \mathrm{ml}$ final volume were inoculated with $10^{5}$ cells / mle final volume and were either stirred immediately $(60 \mathrm{rpm})$ or cultured in a reduced culture volume with intermittent stirring the modified initial culture procedure involuted stirring for $1 \mathrm{~min}$. (30 rpm) After 3 hours, the culture was diluted to the final volume and stirred (60 rpm). Attachment of cells to plastic Petri dishes is indicated.

10.Optimization of micro carrier concentration on the proportion of micro carriers bearing Vero cells at the plateau stage of culture. cultures were inoculated with 5 viable Vero cells/ micro carrier and stirred immediately at 
$60 \mathrm{rpm}$. The proportion of micro carriers bearing cells was determined after 7 days. Cultures were maintained under conditions where supply of medium and control of $\mathrm{pH}$ were not limiting cell growth.

\section{RESULTS}

Figure 1 showed that the change in the media with replenishment medium leading to increase in the cell yield.

Figure 2 showed that the increase in the cell yield with reduced in the final volume culture with intermittent stirring after 7 days. That 5 cells / microcarrier is required through the culture.

Figure 3 showed that the stirring at 60 RPM gave a good result and increase in the cell yield.

Figure 4 showed reduced in the head volume gave a good result and increase in anchorage dependent cells.

Figure 5 showed in using low density of the cell with using medium 199 give a good result but in using high density of the cell with DME gave a good result with maintaining the condition of the culture.
In Figure 6, The use of fetal calf serum for the first three days and then changing to the medium containing newborn calf serum, results in high yield in microcarrier bearing cell.

Figure 7 showed the medium with using $\mathrm{PH}$ with HEPES gave a good result that maintained the $\mathrm{PH}$ of the medium so increasing the cell yield.

Figure 8 showed increasing in the cell yield with modified in the culture volume that if in low density or with high density of the cell.

Figure 9 showed increasing in the cell yield with intermittent stirring and reduced initial culture volume on the rate of attachment of vero cell cytodex-3 microcarriers that modified procedure lead to more efficient utilization of the inoculum. This procedure results in attachment efficiencies comparable to those in plastic petri dishes.

Figure 10 showed that $3 \mathrm{mg}$ cytodex -3 microcarrier gave a good result with maintaining the condition of the culture of $\mathrm{PH}$ and gas tension.

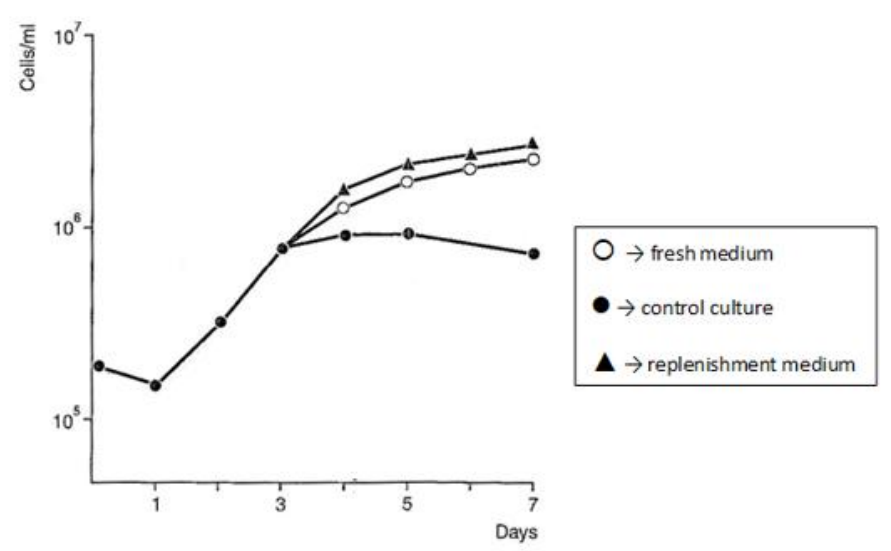

Fig.1: Effect of replenishment, vero cell culture media. the depletion of medium components. during growth of vero cells in micro carrier culture. 


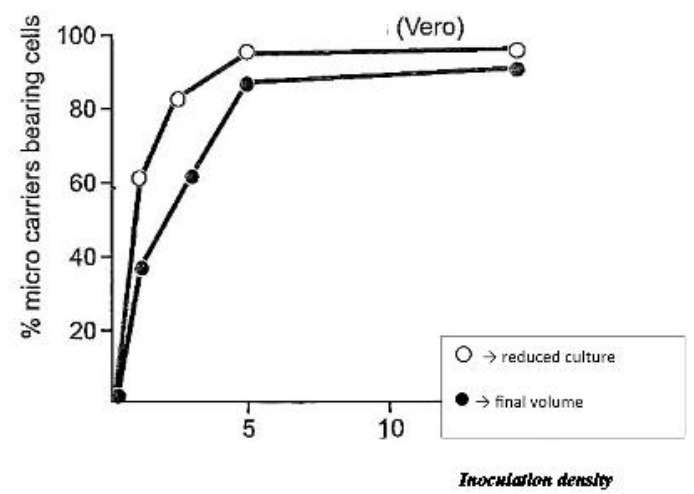

Fig.2: The effect of inoculation density on the proportion of micro carriers bearing cells at the plateau stage of culture. Culture contained $3 \mathrm{mg}$ Cytodex $3 / \mathrm{ml}$.

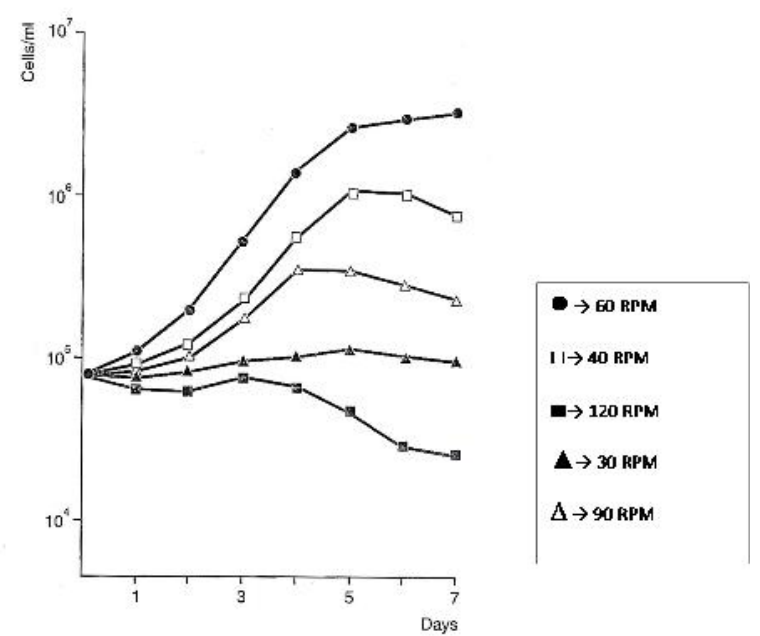

Fig.3: Effects of stirring speed on the growth of vero cells on Cytodex 3 micro carriers.

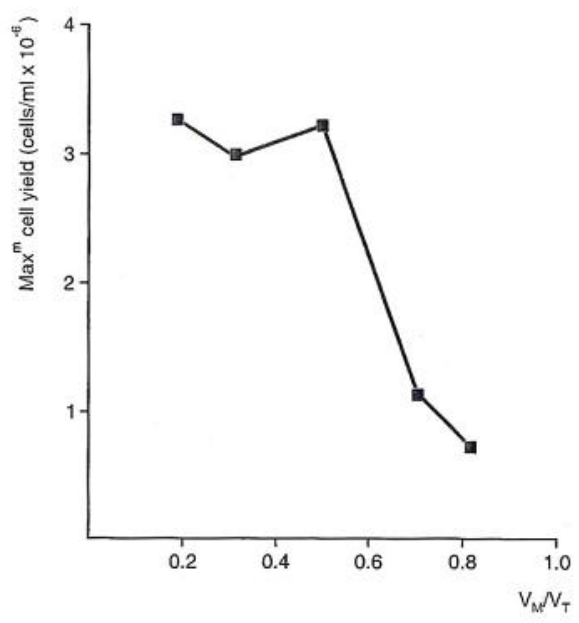

Fig.4: The effect of culture volume and headspace volume on cell yields from a closed micro carrier culture system. 


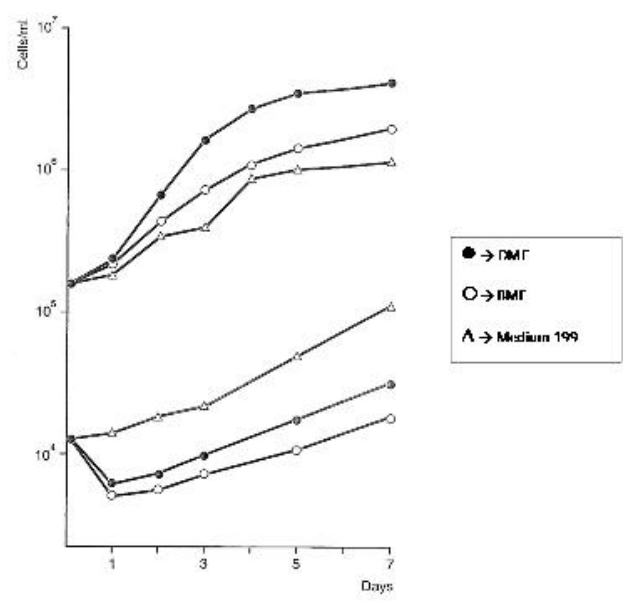

Fig.5: The effect of various culture media on the growth of monkey kidney cells (Vero) on Cytodex micro carriers.

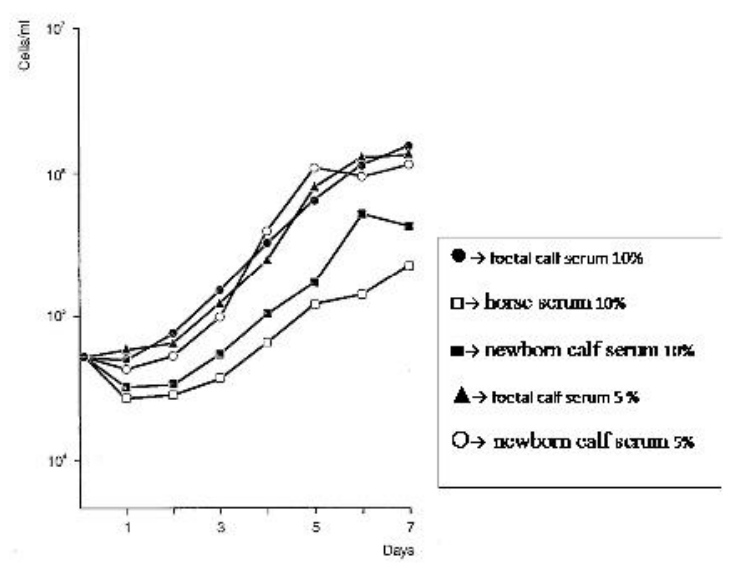

Fig.6: The effect of various types of serum supplement on the growth of monkey kidney cells (Vero) in microcarrier cultures.

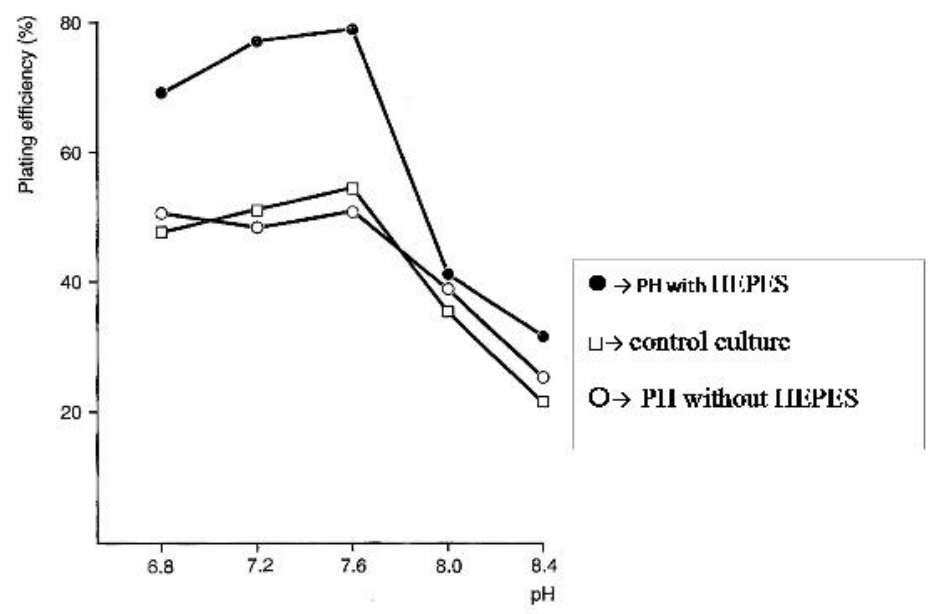

Fig.7: Effect of control of $\mathrm{pH}$ on the growth of vero cells in micro carrier cultures. 


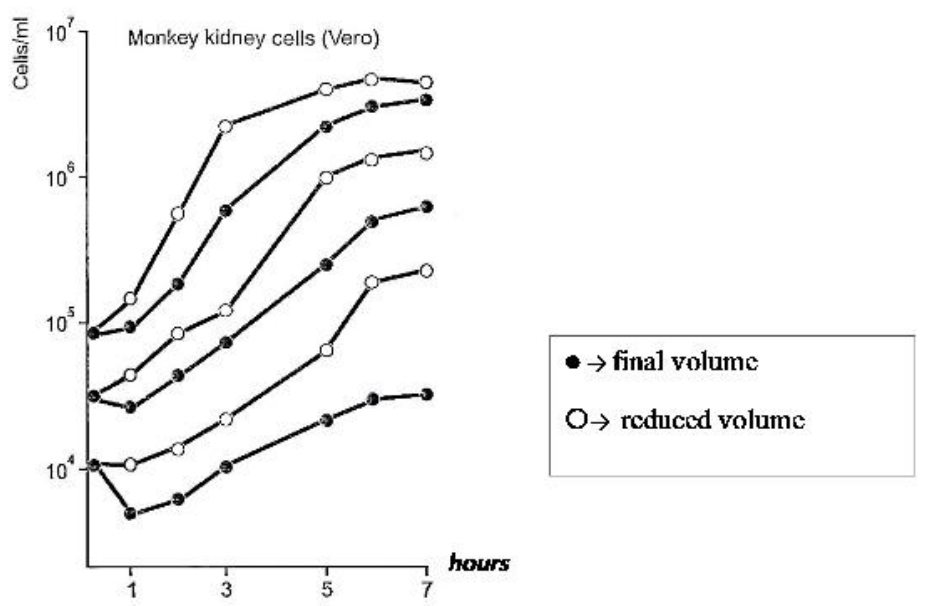

Fig.8: The Effect of inoculation density and initial culture procedure on the growth of Vero cells on Cytodex 3 micro carrier cultures.

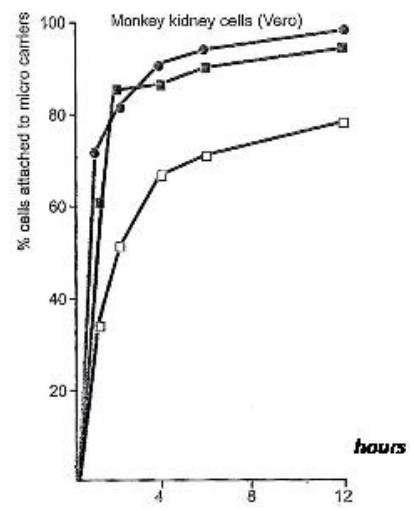

- $\rightarrow$ modified initial culture

$\square \rightarrow$ conlrol culure

- $\rightarrow$ final volume

Fig.9: The effect of initial culture procedure on the attachment efficiency of Vero cells.

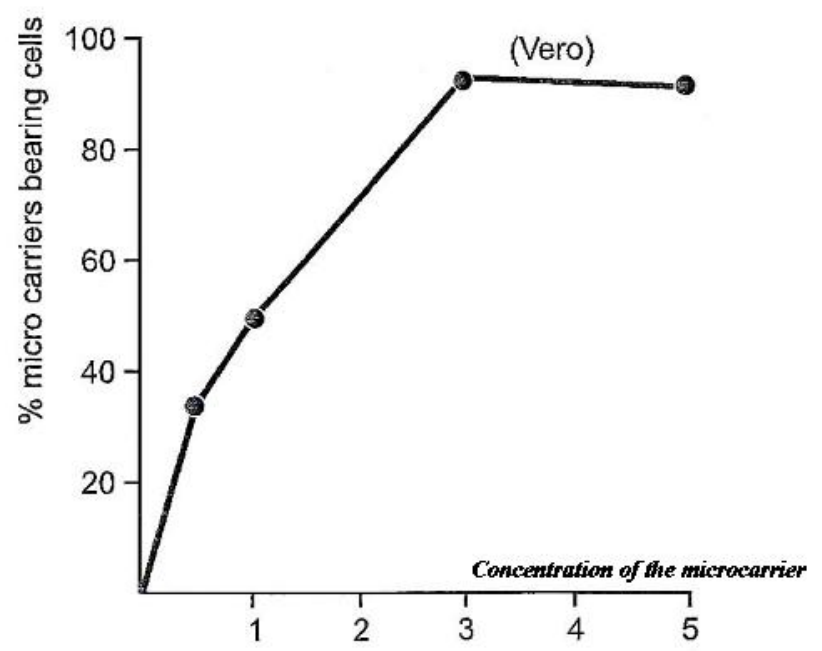

Fig.10: The effect of micro carrier concentration on the proportion of micro carriers. 


\section{DISCUSSION}

The viral vaccines are susceptible to loss it's titer during the storage, distribution so, there are many trials to improve its efficiency by using alternative method of the culture called cytodex- three microcarrier that enhanced in increasing the virus titer so, to increase the yield of the cell by this method must using the optimizing factors that the result revealed the change in the media with replenishment medium during the growth lead to increase the cell yield due to replacing essential nutrients which are depleted by cell growth, removing products of metabolism which inhibit growth or survival the cell on contrast to control culture as in figure 1, (Holly, et al., 1979), (Eagle ,et al., 1973).

In case of low inoculation density with reduced in the final volume at the plateau stage of culture give high proportion of microcarrier behaving cell as in figure 2. (Wilson, et al, 1959).

Effect of stirring speed that at $60 \mathrm{rpm}$ as in give high result that if speed is too fast the cell are dislodged from the microcarrier figure 3.

The culture volume and head space effect on the cell yield that in the culture vessels should be filled not more than half full to help in supply of oxygen and buffering the usual co2bicarbonate as in figure 4 . increase the head space lead to high cell yield. If we start the culture with low density of the cell but after that maintaining the condition of culture with medium 199 lead to high cell yield and incase of starting the culture with high density of cell and using the modified DME give higher cell yield as in figure 5 .(Ham, et al., mckeehan, et al., 1979) .

The result showed the sue of fetal calf serum for the first three days and changing to the medium containing newborn calf serum results in higher cell yield due to induction of promoting factors as in figure 6. (feldman, et al., 1977) (Verger, et al., 1979).
Concentration of $3 \mathrm{mg}$ cytodex/ $\mathrm{ml}$ is usually the optimum concentration give the greatest proportion of microcarrier bearing cell due to decrease than $3 \mathrm{mg}$ depend on ability of the cell to grow under less dens condition and higher concentration than $3 \mathrm{mg}$ the culture medium may need to be replenished more often time so, this concentration is the optimum to get higher cell yield.

Addition of HEPES delays the onset of $\mathrm{pH}$ drift and usually increases cell yield. The HEPES assists in maintaining $\mathrm{pH}$ during the attachment period of culture and plating efficiency is enhanced. Routine addition of 10$25 \mathrm{mM}$ HEPES is advisable when the best results are required from laboratory scale microcarrier cultures. Whenever the tension of $\mathrm{CO} 2$ is low (less than $5 \%$ ) there is a lower stability of the HCO 3 system and HEPES should be used. The exact amount of HEPES should be no more than is required to maintain the $\mathrm{pH}$ and it is advisable to start with $10 \mathrm{mM}$. (Ceccareini, et al., 1975).

The optimum anchorage dependent cells of the vero cell is 15 cell/microcarrier is required during the inoculation density due to the condition affect the cell depend on the density of the culture that low density than 15 cell/microcarriers leading to poor growth with respect to reduce the anchorage dependent cell. The effect of using an attachment period with intermittent stirring and reduced initial culture volume on the rate of attachment of vero-cells to cytodex-3 microcarrier leading good results due to modified procedure leading to more efficient utilization of the inoculum this procedure results in attachment efficiencies comparable to those observed in Petri dish. (McLimans, W.F, et al., 1979).

\section{Conclusion}

The present study aims to increase the yield of vero - cells and so that increase the PPR virus vaccine production. 


\section{REFERENCES}

Ceccarini, C., (1975): Effect of $\mathrm{pH}$ on plating efficiency, serum requirement, and incorporation of radioactive precursors into human cells. In Vitro 11 78-86.

Eagle, H (1973): The effect of environmental $\mathrm{pH}$ on the growth of normal and malignan cells.]. Cell Physiol. 82 1-8.

Feldman, M.K., Wong, D. L (1977): The effects of various mammalian sera on attachment efficiency and thymidine incorporation in primary cultures of mouse mammary epithelial cells. In Vitro 13 275-279.

Holley, R.W., (1979): Control of growth of kidney epithelial cells in culture. Hormones and Cell Culture, Cold Spring Harbor Conferences on Cell Profileration 6 455-459,

McKeehan, W.L, (1979): Media and growth requirements. Methods in Enzymology 58 44-93 Ham, R.G.

McLimans, W.F, (1979): Mass culture of mammalian cells. Methods in Enzymology 58, 194- 211.

Nahapetian A. T, Thomas J. N, Thilly W. G. (1986): Optimization of environment for high density Vero cell culture: effect of dissolved oxygen and nutrient supply on cell growth and changes in metabolites. J Cell Sci.; 81:65-103.

OIE, (2004): Manual of Standards for Diagnostic Tests and Vaccines. $5^{\text {th }}$ Ed., Office Internationale des Epizooties, Paris, France.

Sato J. D, and Kan M. (2001): Media for culture of mammalian cells, Curr Protoc Cell Biol. May; Chapter (1): Unit 1.2.
Verger, C., (1979): Proliferation and morphology of chick embryo cells cultured in the presence of horse serum and hemoglobin. In Vitro 15 587-592.

Wilson, N., (1959): Burt, A.M The bulk growth of animal cells in continuous suspension culture. J. Gen. Microbial, 21 702-720, Cooper, P.D. 